\title{
Heritage Tourism, Conflict, and the Public Interest: An Introduction
}

\author{
Benjamin W. Porter \& Noel B. Salazar
}

Keywords: Heritage Tourism; Public Interest; Stakeholders; Conflict

This special issue explores how and why conflicts arise in the development and practice of heritage tourism. From New York City's Ground Zero and the archaeological site of Chichén Itzá in Yucatan, Mexico, to an Underground Railroad site in Pennsylvania and a post-industrial Massachusetts town, the authors of these four articles are concerned with identifying the often overlapping interests of stakeholders in their attempts to gain access to and guide the development of heritage resources. This issue grows out of a 2003 symposium entitled 'Resolving Conflicts in Heritage Tourism: A Public Interest Anthropology Approach', at the 102nd annual meeting of the American Anthropological Association in Chicago, Illinois, organised by Dr Peggy Reeves Sanday, Noel Salazar, and Benjamin Porter of the University of Pennsylvania. The symposium encouraged scholars to consider heritage apart from official and 'top-down' definitions as well as how an emerging methodological approach, public interest anthropology (PIA hereafter), ${ }^{1}$ could be applied to the analysis of heritage conflicts.

This introduction places the issue's key themes of heritage, tourism, conflict, and the public interest in focus and illustrates their intersection in a brief case study from modern Jordan. Following this, the four ensuing articles are discussed with an emphasis on their contributions to the issue's themes. Heritage and heritage tourism are longfamiliar terms to this journal's readership and our goal here is not to recapitulate what others have described so well elsewhere. ${ }^{2}$ In particular, we analyse a process of revaluation that objects, sites, and practices undergo before they are placed within the domain of heritage. Additionally, we explain why tourism is an ideal realm in which to investigate heritage and why the conflicts that erupt around heritage tourism are particularly volatile.

Benjamin Porter \& Noel Salazar, University of Pennsylvania. Correspondence to: bporter@sas.upenn.edu 


\section{Heritage, Heritage Tourism Conflicts and the Public Interest}

This meditation on heritage is not alone in the commonly observed point that the concept is not easily defined. ${ }^{3}$ A cross-disciplinary literature review suggests that the products of heritage-development, tourism, and management-are far easier to document than the concept itself. Treatises on the subject quickly move from a discussion of definition to lengthy examples. Can we discover something new about the phenomenon of heritage when it is uncoupled from common partnerships of management, preservation, and tourism?

Recent writings that confront heritage directly suggest that we can gain much from such an endeavour. While it is possible to speak of multiple and nested types of heritageglobal, diasporic, national, or otherwise, ${ }^{4}$ often missing from these discussions are definitions that acknowledge heritage at its basic, generative levels. Heritage, from an analytical perspective, exhibits both intensional and extensional definitions. As an intensional definition, heritage presents itself as 'a sense of the self in the past' where the subjective component of 'self' is ascribed at increasingly broad scales of the individual, community, nation, and globe, and the temporal links between the subject and the past are based on perceived genealogical, biological, or community connections. On the other hand, an extensional definition requires actually locating concrete manifestations of 'heritage' in the world. Language and other practices are the vehicles through which human understandings of the past are expressed. Objects, too, come to embody these ideas and represent and communicate past times in the present. While no single utterance, practice or object may fully represent a society's heritage, these instances become bound in various publicly accessible discourses that inform the scope and accuracy of the term.

Around the world, heritage's objectifying process has ascribed inalienable qualities to places, objects, and practices, initiating a host of activities around them, from performance and display, to preservation and tourism. We have chosen the final term as the practice through which to explore heritage as the investigation of tourism, heritage tourism in particular, has shown itself to be a most productive window in understanding modernity. ${ }^{5}$ As a sub-genre in the tourism business, heritage tourism is now an industry of such global proportions that the local consequences that it produces have generated vibrant discussions over its definition, organisation, and sustainability. ${ }^{6}$ Conflict - its management, resolution and consequences - is a recurring theme in these conversations and remains one of the most vexing issues to scholars. The following examinations of heritage tourism are preoccupied with episodes of conflict that occur between stakeholders-guests, hosts, development agencies, and local communitiesover site access, development, and management.

Observations of conflict and violence in heritage tourism are not enough, however; rather, we are drawn by the need to explain how and why conflict appears in the first place. Surely, as analysts, we are intrigued by iterations of conflict in that they are interesting and in most need of our attention. But we should not assume that every heritage destination is contested. It is the analyst's gaze that has focused on the Jerusalems and Stonehenges of the world that has made conflict part of heritage tourism's thematic baggage. 
If conflict, then, is not an inherent quality of heritage tourism, is it possible to understand why conflicts arise and perhaps identify the conditions in place that introduce conflict into heritage tourism? Often, the pretext of heritage consists of inalienable value coupled with select stewardship. The perceived inalienable qualities of heritage materials and practices have resulted in the perception of heritage as a non-renewable and often non-replicable resource. This perception is most readily observed in the contests that quickly arise when commercial development threatens to obliterate places and things: they are quickly promoted from valueless to valuable. This perceived notion of value greatly informs a second factor in heritage tourism conflicts-stewardship. If such materials are rare and beyond replication, who holds the rights to manage such precious resources? Stakeholders' desires to manage their heritage do not always translate into stewardship rights. Stakeholders often willingly or unwillingly surrender development and management responsibilities to government organisations, along with the privilege to shape the site's public representation. When stakeholders are not stewards, the heritage they believe so inalienable takes on a representation beyond their control and limits them in their ability to participate in an idea they believe uniquely their own. It is when value is disproportionately high compared to stakeholders' role in stewardship that we find ourselves on the verge of heritage tourism conflicts.

The authors in this issue are concerned with the various stakeholders who participate in heritage tourism conflicts and look to a public interest approach to frame their analysis. PIA 'promotes change and advances knowledge through attention to the "dilemmas" and "perplexities" of our time as these are articulated in civil society, the arena where social issues circulate and people come together in pursuit of common goals'. ${ }^{7}$ Given its sensitivity to conflict and dialogue within civil society, PIA is rightly poised to examine ensuing conflicts in the global proliferation of heritage. PIA places civil society at the centre of analysis, investigating how groups form and conflict with other groups in the promotion of their interests. An important aspect of PIA is participatory action research, where the scholar acts as both researcher and public advocate, aggressively investigating the reasons for conflict, presenting findings to all parties, and participating - when invited-in consensus building. At the same time, the analyst remains aware of disparities in power across involved groups and seeks to readdress this imbalance in the debate. As scholarship and advocacy combined, PIA offers a powerful research design with which to explore heritage anew, providing the scholar with a means to further the goals of social science inquiry while promoting conflict resolution and dialogue in civil society.

Because there is only limited space to explore this issue's principal themes in the abstract, we now turn to a brief example from Jordan to illustrate how a public interest approach can be applied to the analysis and resolution of heritage tourism conflicts.

\section{A Case Study from Central Jordan}

Central Jordan, where local and more institutionalised understandings of heritage have diverged, presents an illustrative case study in the issues discussed above. Officially, the Hashemite Kingdom of Jordan separates heritage, turāth, from history, tārīkh, 
chronologically; all customs, foods, and buildings after $1700 \mathrm{CE}$ are designated turāth, while the same before this date are consigned to tāri $k h$. However, these official definitions are often obscured in practice; that is, turäth quickly overlaps with and subsumes tārì kh. At the same time, a national Jordanian turāth is undergoing commodification aimed at domestic and foreign tourists alike. ${ }^{8}$ Arabic and English-language newspapers avidly promote a consumption-driven attitude that equates the terms turāth and heritage. At these intersections, particular products, places, and ideas both reflect and signify each other. Rugs, furniture, paintings, and jewellery are advertised as part of a national heritage that one owns and displays in one's house. Moreover, the Roman theatres of Amman, Jerash, and Umm Qais annually host European classical as well as Arabic pop musical performances, where audiences suffer the uncomfortable stone seating to be entertained 'like Romans'. One can spend the weekend at the Mövenpick Resort on the Dead Sea where an Ottoman village comes to life, this time with an abundance of water, flowers, sumptuous ice cream, and Shiatsu massage (see Figure 1). 'Perfect' participation in this exciting, sophisticated turāth involves purchasing objects and attending events, i.e. owning heritage; more often than not, it is restricted to Jordan's privileged, professional class. Ultimately, as international tourism revenue is highly volatile, the Kingdom is turning to its own as well as the neighbouring countries' wealthy elites to participate in an emerging heritage tourism that celebrates a pan-Arab and pan-Islamic identity.

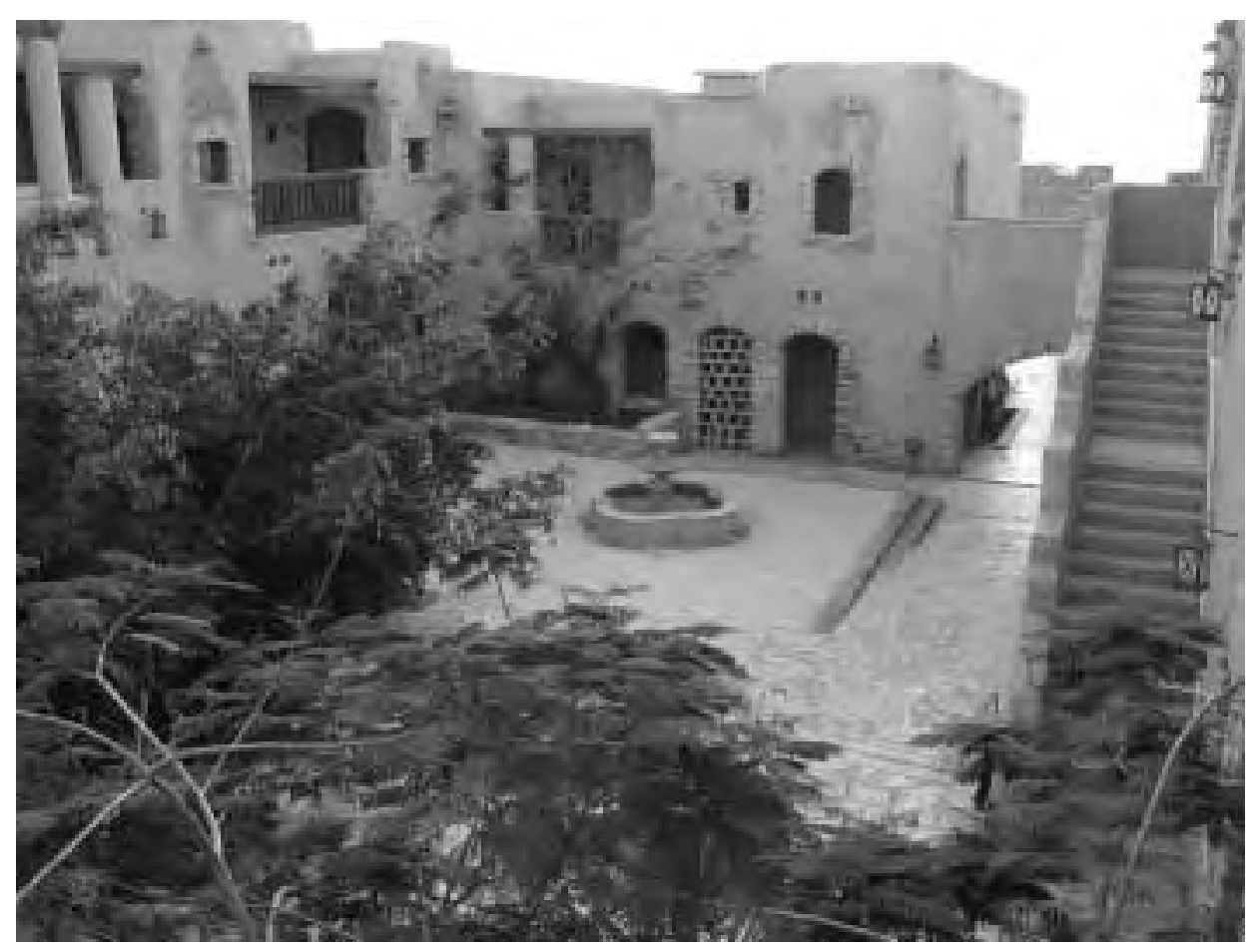

Figure 1 Accommodation at the Mövenpick Dead Sea Resort permits guests to experience the Ottoman-period village, albeit cleaner with a spa and pool. 
Quite contrastingly, a greater level of discernment between turāth and tärikh is occurring in the rural communities of Central Jordan. There is tacit agreement within local society that a genealogical relationship exists between the 18th- and 19th-century residents of the area and themselves. This period weighs heavily on the historical memory of modern Jordanians and, not surprisingly, many ideas about heritage are drawn from this era. The late 19th century is celebrated as a time of resistance against foreign Ottoman occupation followed by a period of self-determination under the Hashemite monarchy. Today, Jordan's Ottoman period is remembered for independent and noble tribesmen who offered hospitality to strangers while raiding the flocks of their neighbours and eluding imperial tax collectors. Locals today say they continue with the same traditions - the hospitality of offering tea to strangers, and the displaying of heirloom rugs, coffee pots and weapons in modern houses.

Jordan depends greatly on revenue from its tourism industry and the Kingdom's Ministry of Tourism and Department of Antiquities continue to work hard to transform the Kingdom's ancient resources into revenue generators. ${ }^{9}$ Upon tourist development in the region, public access to sites is reduced, separating communities from the surrounding landscape through fences, guards, parking lots, and ticket booths. Local meanings circulating around the site encounter highly formalised narratives, constructed through interplay between archaeological research and tourist development-tourist development that is heavily promoted by the Hashemite royals in the international media. Where children once heard stories about antiquity sites and the past from an older generation, they now encounter the past, and their place in that past, from national, institutionalised narratives in schools, textbooks, art exhibitions, and popular media.

The differences described here between local and national heritage discourses are emerging slowly and what effects one will bear on the other are still unknown. Will national and regional definitions subsume local ones? Will the two remain compatible, each operating at different scales and with different audiences, one more formal than the other? Will local communities resist these official narratives if they are not incorporated into the tourist infrastructure of guiding and hospitality management?

A PIA framework is guiding this investigation of turāth and tārìkh in the development of one particular site in central Jordan, Tall Dhiban. Starting in the summer of 2004, with the permission of Jordan's Department of Antiquities, a joint University of Pennsylvania, University of Liverpool, and Stanford University team began excavations and development of ancient Dhiban, a prominent tall situated next to the modern town bearing the same name (see Figure 2). ${ }^{10}$ Earlier excavations at the site revealed an occupational history of 5,000 years spanning the Bronze, Iron, Roman, Byzantine, and Islamic Ages. ${ }^{11}$ The project promises to be a multi-faceted endeavour where scholars work collaboratively with the local community, national authorities, and foreign granting agencies to explore new ways of fostering sustainable economies while conducting sound archaeological research. Compared to Madaba, a neighbouring community with an expanding tourist economy, Dhiban is less wealthy, with few economic opportunities besides seasonal agrarian labour. The Jordanian government has often taken the lead in developing archaeological sites for tourism, leaving the community to develop 


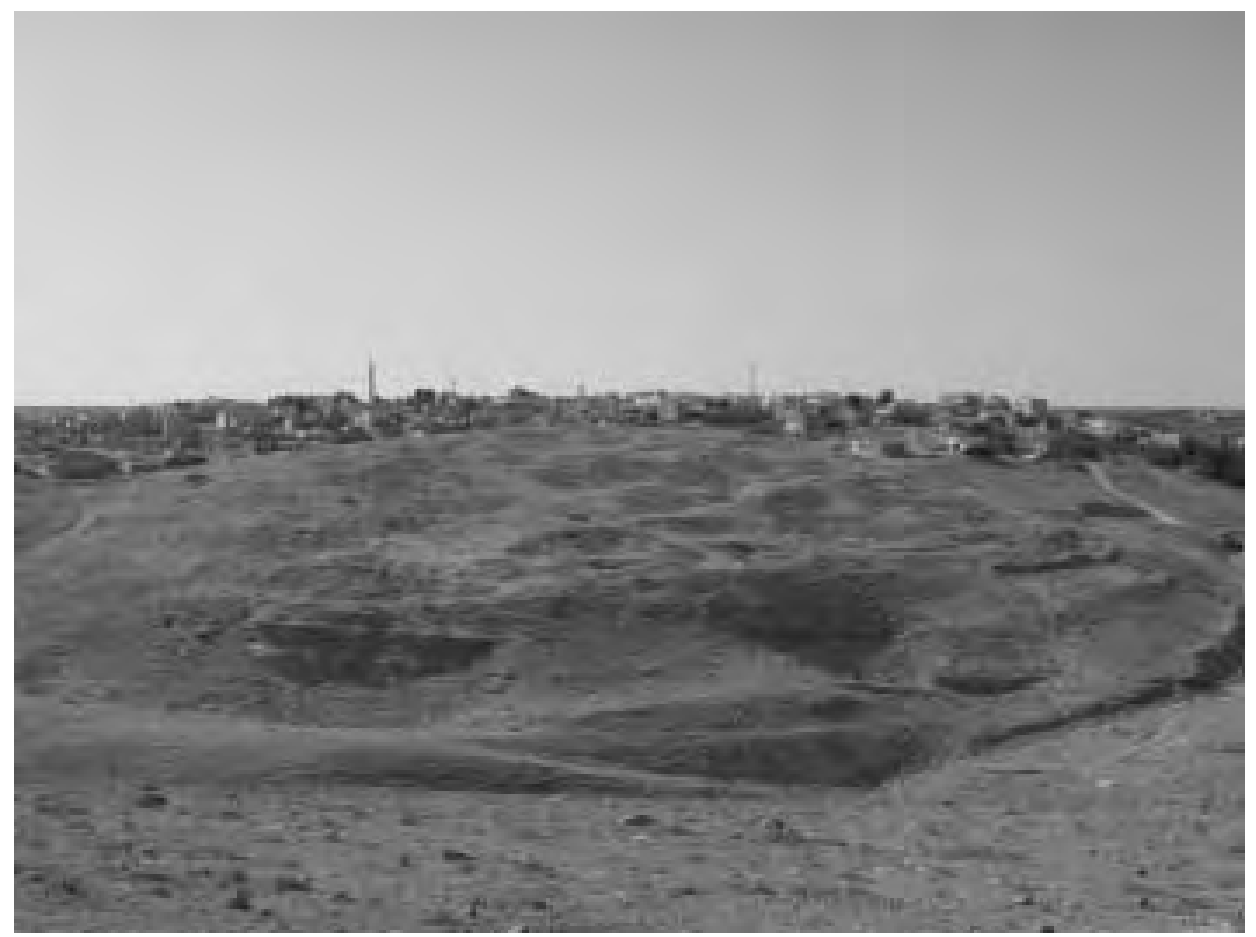

Figure 2 Ancient Tall Dhiban with modern Dhiban in the background, looking south.

a service economy (e.g. hotels, kiosks) with limited assistance. As an alternative, the team is working with the Dhiban community to identify and foster community-based initiatives that will lead to sustainable employment opportunities. The primary goal is to establish a space at Dhiban where domestic and international visitors can experience both a fair representation of local heritage as well as partake in a dialogue concerning the region and Kingdom's history.

Issues of use value versus conventional ideas of preservation and development are in competition at Dhiban. The community currently uses the site as a pasture, picnic spot, playground, garbage dump, quarry, and meeting site. Tourism development will potentially alter these types of activities, as fences, guards, tourists, and signs come to dictate its use. Are community members willing to exchange this unhindered access for a source of income-income that Jordanians have come to see as unreliable in the wake of recent unprofitable tourist seasons? The challenge here is to shape a collaborative atmosphere that will create a space that is an economically viable resource, while at the same time allowing these activities to continue either in this space or in other locations.

We are also learning that traditions of hierarchy already structure discussions of Dhiban's future. A second challenge is ensuring inclusive participation by all segments of the community, women and children included, in the site's public representation and development. Their opinions need to be considered alongside the traditional powerbrokers of development-foreign funding agencies, government representatives, and 
archaeologists. The team has initiated an interview project in collaboration with community members to record the meanings that circulate around the site. Accommodating these multiple standards will be possible through town meetings, school involvement, participation in the excavation, and interpretation of excavated evidence. In particular, town meetings have proved useful in other development projects in Jordan and will potentially foster the necessary cooperation of the various stakeholders in order to fairly distribute the benefits brought about by development.

\section{Case Studies in Heritage Tourism Conflicts}

As in the example presented above, the themes of heritage tourism, conflict, and the public interest are explored in four case studies in this issue. Elizabeth Greenspan, in 'A Global Site of Heritage? Constructing Spaces of Memory at the World Trade Center Site', illustrates the divide between vernacular and official modes of memorialisation at the World Trade Center (WTC) site during the year following the attacks of 11 September 2001. Noting that people produce meaning in physical spaces through ritualised performance, Greenspan observes how domestic and international visitors' daily practices articulated a global heritage destination. The author's work at the WTC site, documented through interviews and photography, pays particular attention to the language and objects people used to create meaning around the site in installations, messages, and flowers. Altogether, these memorials along the site's boundaries encouraged ongoing participation in the construction of heritage; as Greenspan writes: 'the very temporary nature of the site's materiality welcomed visitors to join in on a collective project of remembrance and grieving'. All of these vernacular efforts, however, soon disappeared and were replaced with the city's official placards.

The local politics of another global heritage site is examined at Chichén Itzá in Mexico. In the second piece, in 'Keeping World Heritage in the Family: A Genealogy of Maya Labour at Chichén Itzá' Lisa Breglia discusses how Maya residents employed at the site have obtained an elite status in the local community by passing on their rights as the site's stewards from one generation to the next. This economic monopoly has created conflict in the community as disenfranchised residents argue for employment opportunities at the site. This 'micro-politics of patrimony', as Breglia has described it, illustrate the extent to which heritage tourism conflicts play out on the local level over economic, rather than heritage, concerns.

Next, Mary Ann Levine, Kelly Britt, and James Delle report on their work at the Thaddeus Stevens and Lydia Hamilton Smith Historic Site in Lancaster, Pennsylvania. Here the authors were called on to excavate the historic home prior to the construction of a convention centre in Lancaster's 18th-century downtown neighbourhood. During excavation, the authors discovered what they interpret to be a modified cistern designed to hide fugitive slaves escaping along the Underground Railroad. The renewed interests in the house's preservation that arose upon the cistern's discovery instigated conflict with both commercial developers and politically conservative citizens. At the same time, the authors designed and promoted a learning programme in 
the elementary schools intended to disseminate information on the Underground Railroad in general, and the Stevens/Smith house in particular.

In the final article, 'Serving Up Culture: Heritage and its Discontents at an Industrial History Site', Cathy Stanton examines folk-life demonstrations at an industrial heritage site in Lowell, Massachusetts. Here, Stanton follows the event from its initial planning to its completion, observing how participants and audience members alike found the event unsatisfying and succeeded in exoticising the performers in a conventional form of cultural display. Stanton is challenging us as analysts to participate more fully in heritage planning, given our privileged position as outside observers; scholars of heritage have much to offer in terms of planning, management, and conflict resolution.

When placing these articles side by side, several interesting points emerge that speak to the larger themes of this issue. The process by which sites, objects, and practices are transformed into heritage is readily observed in the examples of Greenspan, Stanton, and Levine et al. Visitors' grief over and sympathy for the victims of the 11 September 2001 attacks inspire a shared sense of global solidarity that is expressed in messages and memorials left at the WTC site. At a heritage centre in Lowell, knowledge workers transform their desire to awaken the community's awareness of local immigrant communities and inspire an appreciation of local diversity into a folk-life presentation. Archaeological research transforms a long-forgotten 19th-century historic home into a contest between commercial space, race politics, and urban preservation. In each instance, space, objects, and practices were revalued and celebrated for the meanings they represented.

The papers presented in this issue provide us with concentrated examples of conflicts in heritage tourism, albeit at different scales. Greenspan and Breglia examine conflicts in the making and management of global heritage sites at the WTC site and Chichén Itzá, while Stanton and Levine et al. scrutinise the local politics of representation in two mid-size urban centres in Lowell and Lancaster. While international organisations have designated Chichén Itzá an official World Heritage Site, the WTC site achieved a global register through international visitors' everyday acts of memorialisation. Regardless of their endorsements, these global sites are both examples of the ways stakeholders, unemployed residents of Chichén Itzá, and grieving visitors to the WTC site are limited in their desires to exercise some degree of stewardship over the site for both tangible and intangible benefits. Stanton and Levine et al., on the other hand, examine the everyday conflicts that arise in local heritage management. The local politics of representation are at play in Lowell as the decision to host a folk-life demonstration showcasing the cuisine of recent immigrant communities results in the exoticising of cultural practices, and in Lancaster, where conservative local voices and commercial interests agree, albeit for different reasons, that a rare remnant of the Underground Railroad should not be preserved.

Finally, each author considers these conflicts in terms of a PIA framework in two specific ways. First, Greenspan, Breglia, and Levine et al. consider the disparity in power and access between various stakeholder communities. All three examples demonstrate how the power of commercial interests, governing bodies, or simply tradition challenge discussions of heritage and deny stakeholders a voice in the management of heritage spaces. At least two papers (those of Stanton and Levine et al.) describe 
attempts to carry out participatory action research, a second way authors incorporate a PIA framework. Levine et al. examine stakeholders' opposing claims in the preservation of the Underground Railroad site while at the same time distributing information about the site in the community to ensure that as many community voices are heard. Stanton is working alongside knowledge producers in order to examine their effectiveness in organising heritage tourism events with the goal of reporting her conclusions to them. Stanton argues for a 're-envisioning' of the relationship between analyst and stakeholder so that 'all of us operating in these discursive fields can see ourselves as people working to create a community of representation rather than simply a representation of community'. All in all, these examples demonstrate that a public interest framework is an appropriate lens through which to understand the nature of conflicts in heritage tourism research.

\section{Acknowledgements}

The authors of this introduction dedicate their efforts to Professor Peggy Reeves Sanday who through her writing on and teaching of PIA has inspired a generation of students to use their privileged positions as researchers to investigate inequalities in civil society. In addition, we would like to thank all the participants in the session 'Resolving Conflicts in Heritage Tourism: A Public Interest Anthropology Approach' during the annual meetings of the 2003 American Anthropological Association, especially those who contributed to this issue. Additionally, we extend our appreciation to Kathleen Adams for her verbal comments at the conference as well as her written critique in this issue, and also to two anonymous reviewers for their helpful comments.

\section{Notes}

[1] Sanday, 'Defining Public Interest Anthropology', http://www.sas upenn.edu/anthro/CPIA/ whatispia/ pia1998.html

[2] See, for example, Graham et al., A Geography of Heritage; and Timothy and Boyd, Heritage Tourism.

[3] Brett, The Construction of Heritage, 1; Graburn, 'Learning to Consume'; Graham et al., A Geography of Heritage, 1-4; and Timothy and Boyd, Heritage Tourism, 2.

[4] Appadurai, 'The Globalization of Archaeology and Heritage'; Graham et al., A Geography of Heritage.

[5] MacCannell, The Tourist; Nuryanti, 'Heritage and Postmodern Tourism'.

[6] See, for example, Garrod and Fyall, 'Managing Heritage Tourism' and 'Heritage Tourism'; and Poria et al., 'The Core of Heritage Tourism' and 'Clarifying Heritage Tourism'.

[7] Sanday, 'Defining Public Interest Anthropology', http://www.sas upenn.edu/anthro/CPIA/ whatispia/ pia1998.html

[8] Kelly, 'Tourism, Not Terrorism'.

[9] Tell, 'Archaeology Today'.

[10] Porter et al., 'The 2004 Season at Dhiban'.

[11] Morton, 'The 1954, 55, and 65 Excavations at Dhiban in Jordan'; Tushingham, The Excavations at Dibon (Dhiban) in Moab; and Winnett and Reed, The Excavations at Dibon (Dhiban) in Moab. 


\section{References}

Appadurai, A. 'The Globalization of Archaeology and Heritage'. Journal of Social Archaeology 1, no. 1 (2001): 35-49.

Brett, D. The Construction of Heritage. Cork: Cork University Press, 1996.

Garrod, B. and A. Fyall. 'Managing Heritage Tourism'. Annals of Tourism Research 27, no. 3 (2000): 682-708.

Garrod, B. and A. Fyall. 'Heritage Tourism: A Question of Definition'. Annals of Tourism Research 28, no. 4 (2001): 1049-52.

Graburn, N. H. 'Learning to Consume: What is Heritage and When is it Traditional?' In Consuming Tradition, Manufacturing Heritage: Global Norms and Urban Forms in the Age of Tourism, edited by N. al-Sayyad. London: Routledge, 2001.

Graham, B., G. J. Ashworth, and J. E. Tunbridge. A Geography of Heritage: Power, Culture, and Economy. London: Arnold, 2000.

Kelly, M. 'Tourism, Not Terrorism: The Visual Politics of Presenting Jordan as an International Tourist Destination'. Visual Anthropology 11 (1998): 191-205.

MacCannell, D. The Tourist: A New Theory of the Leisure Class, 2nd edition Berkeley: University of California Press, 1999 [1976].

Morton, W. 'The 1954, 55, and 65 Excavations at Dhiban in Jordan'. In Studies in the Mesha Inscription and Moab, edited by A. Dearman. Atlanta: Scholars Press, 1989.

Nuryanti, W. 'Heritage and Postmodern Tourism'. Annals of Tourism Research 23, no. 2 (1996): 249-60.

Poria, Y., R. Butler, and D. Airey. 'Clarifying Heritage Tourism'. Annals of Tourism Research 28, no. 4 (2001): 1047-49.

—. 'The Core of Heritage Tourism'. Annals of Tourism Research 30, no. 1 (2003): 238-54.

Porter, B. et al. 'The 2004 Season at Dhiban: Prospection, Preservation, and Planning'. Annual of the Department of Antiquities of Jordan (forthcoming).

Tell, S. 'Archaeology Today: Its Motives, Significance, Procedures, Political Aspects, and Problems. General Perspectives of Jordan'. In Partnership in Archaeology: Perspectives of a Cross-cultural Dialogue, edited by B. Sitter-Liver and C. Uehlinger. Fribourg: Fribourg University Press, 1997.

Timothy, D. and S. Boyd. Heritage Tourism. Harlow: Prentice Hall, 2003.

Tushingham, A. D. The Excavations at Dibon (Dhiban) in Moab: The Third Campaign. Annual of the American Schools of Oriental Research, vol. 40. Cambridge: American Schools of Oriental Research, 1972.

Winnett, F. and W. Reed. The Excavations at Dibon (Dhiban) in Moab: The First and Second Campaigns. Annual of the American Schools of Oriental Research, vols 36-37. Baltimore: J. H. Furst, 1964. 